\title{
The Relationship between Haematologic indices/Immunologic markers and HIV disease in Antiretroviral-naïve HIV seropositive Individuals in the Niger Delta Region of Nigeria.
}

\author{
Nwabuko $\mathrm{CO}^{1}$, Chukwuonye $\mathrm{II}^{2}$,Nnoli $\mathrm{M}^{3}$,Chuku $\mathrm{A}^{4}$,Ejele $\mathrm{OA}^{5}$ \\ ${ }^{1}$ Department ofHaematology, Federal Medical Centre, Umuahia. \\ ${ }^{2}$ Department of Internal Medicine, Federal Medical Centre, Umuahia \\ ${ }^{3}$ Department ofHisto-Pathology, University of Calabar Teaching Hospital. \\ ${ }^{4}$ Department of Ophthalmology, Federal Medical Centre,Umuahia. \\ ${ }^{5}$ Department of Haematology, University of Port Harcourt Teaching Hospital.
}

\begin{abstract}
Aims and objectives:To determine the relationship between Haematologic indices and immunologic marker in prediction of HIV disease in patients in the Niger delta region of Nigeria

Methodology: Fifty anti-retroviral drugs naïve HIV-infected adult subjects aged 20-55 years and 50 matched controls were recruited from January-December, 2009 at Haematology clinic of the University of Port Harcourt Teaching Hospital. Samples were collected for complete blood count, Erythrocyte Sedimentation Rate, Retroviral screening and confirmation, and CD4 positive T-lymphocyte count.

RESULTS: The mean ESR in HIV-infected patients $(97.46 \pm 39.9 \mathrm{~mm} / \mathrm{hr})$ and that of the control was $(10.1 \pm$ $5.7 \mathrm{~mm} / \mathrm{hr}$ ). The mean Haemoglobin concentration, ALC, Platelet count and CD4 positive lymphocyte count of HIV-infected patients were $10.9 \pm 2.0 \mathrm{~g} / \mathrm{dl}$ or $0.33 \pm 0.06 \mathrm{~L} / \mathrm{L}, 3283 \pm 691 \mathrm{cells} / \mathrm{mm}^{3}, 157000 \pm 81979 \mathrm{cells} / \mu \mathrm{l}$ and $217.0 \pm 144.8 \mathrm{cells} / \mu \mathrm{l}$ respectively and that of the control were $14.3 \pm 1.5 \mathrm{~g} / \mathrm{dl}$ or $0.43 \pm 0.045 \mathrm{~L} / \mathrm{L}, 4746 \pm$ $1263 \mathrm{cells} / \mathrm{mm}^{3}, 197660 \pm 48742 \mathrm{cells} / \mu \mathrm{l}$ and $896.2 \pm 198.0 \mathrm{cells} / \mu \mathrm{l}$ respectively. CD4 positive lymphocyte count was weakly inversely correlated to ESR in both patients and control $(r=-0.18 ;-0.11$ respectively), and weakly directly correlated to ALC $(r=0.18 ; r=0.24)$, Haematocrit $(r=0.07 ; r=0.31)$ and platelet count $(r=$ $0.05 ; r=0.08$.

Conclusion: Elevated ESR, decreased Haematocrit, ALC and Platelet count are essential haematologic predictive markers of HIV disease progression in resource limited centre's, though they may not be useful surrogate to CD4 count.
\end{abstract}

Key Words:HIV, Correlationship, Haematologic markers, Immune predictive marker.

\section{Introduction:}

One of the public health problems of this age is HIV/AIDS pandemic. At the end of 2007, the Joint United Nations Program on HIV/AIDS (UNAIDS) estimated that, globally, 33.2 million adults and children were living with HIV/AIDS. Sub-Saharan Africa remains the most seriously affected region with AIDS remaining the leading cause of death there. ${ }^{1-2}$

Nigeria is Africa's most populous nation with a population estimated at well over 140 million in 2006.The adult HIV prevalence has increased from $0.4 \%$ in 1988 to $5.8 \%$ in 2001.Thereafter the prevalence decreased from $5.0 \%$ in 2003 to $3.1 \%$ in 2009 . That is to say that about 4.32 million Nigerians ( $3.1 \%$ Nigerians) is living with HIV/AIDS even though the 2009 estimate was 2.6 million because the population was based on sentinel surveillance of antenatal clinic attendance. Rivers state, a state in the Niger Delta Region of Nigeria, accounts for about 365,000 (about 7.3\% of over 5 million inhabitants of Rivers state are living with HIV/AIDS). ${ }^{3,4}$

The impact of the epidemic on the social and economic development of Nigeria has been substantial. It has contributed to the present decrease in life expectancy, increased the number of deaths of young adults and increased the number of orphans in the country (estimated at one orphan in every 15-24 HIV/AIDS-related deaths).It has also increased the cost of achieving developmental goals and increased the level of poverty in the country.

The Federal Ministry of Health, as part of measures to respond to HIV/AIDS epidemic in this region, had to scale up the care, treatment and support of people living with HIV/AIDS through various agencies and non-governmental organizations (NGO's). ${ }^{5}$

However, one of the greatest health challenges facing HIV-related care in the Niger Delta region is the evaluation of baseline CD4 positive lymphocyte count of HIV-seropositve individuals, a parameter essential in predicting disease progression and the decision-making process of when to start Highly Active Anti-retroviral Therapy (HAART) 
Since investigation facilities determine accreditation for donor driven therapy, there is therefore need to evolve low cost tests in order to access care and treatment of people living with HIV/AIDS in resource constraint settings like those found in the Niger delta region.

The present research is aimed at determining the relationship between CD4 positive lymphocyte count and these essential haematological parameters and to ascertain if they can be used as surrogate for CD4 positive lymphocyte counts in resource limited settings sub-Saharan African countries.

\section{Materials And Method:}

The study was carried out at the University of Port Harcourt Teaching Hospital, Port Harcourt, River state. The study population was HIV-infected, antiretroviral- naïve subjects of both sexes aged 18 years and above enrolled into the antiretroviral therapy program at the Haematology department of the University of Port Harcourt Teaching Hospital (UPTH) from January-December, 2009. Ethical clearance for the study was obtained from the ethical committee of the University of Port Harcourt Teaching Hospital. Written and informed consent was obtained from all the HIV subjects before being enlisted into the study.

A total of fifty (50) HIV- seropositve antiretroviral- naïve adults patients and 50 age and sex matched controls who were healthy HIV seronegative prospective blood donors were studied between January and December, 2009. About ten (10) milliliters of whole venous blood samples was collected by clean venepuncture using a 10millilitres hypodermic syringe and needle from each patient. About two (2) milliliters and five (5) milliliters of the blood were placed inside dipotassium EDTA (ethylene diamine tetra-acetic acid or sequestrene) anticoagulated plastic bottles for CD4 test and Complete Blood Count (with ESR) analysis respectively. The remaining 3 milliliters of blood was put in a plain tube without anticoagulant; centrifuged at $3000 \mathrm{rpm}$ for 10 minutes and serum samples obtained.

The serum sample was screened for the presence of HIV antibodies using Enzyme Linked Immunosorbent Assay (ELISA) technique. In this study double ELISA technique was used. The first was Gene screen (Sanofi, Pasteur) test kit. All initial reactive samples were re-tested with another ELISA test kit (Biorad, France) for the purpose of eliminating those samples presenting false reaction at the initial stage. Serum samples that were positive by second ELISA technique were confirmed using Immunocomb (Orgenics, Isreal) or Western blot (Biotech, Ireland) .

The EDTA anti-coagulated blood ( 2 milliliters) was used for CD4 positive lymphocyte evaluation using the flow cytometric technique. Here, 20 microlitre of whole blood was added to 20 microlitre of anti CD4 monoclonal antibody. The mixtures were incubated in dark cupboard for about 10minutes before adding 800 microlitre of buffer solution to the tube. Thereafter, the entire mixture was transferred to the flow cytometer for evaluation of the $\mathrm{CD} 4^{+}$lymphocyte count of the patient.

The ESR was determined using the Westergren graduated tube method while the complete blood count was done using automated coulter machine

All data were entered and analyzed using EPI info statistical software version 6.02. Statistical analysis of mean and standard deviation were calculated. Student t-test was used to test the significance of differences between mean values. A probability (p) less than 0.05 were taken to indicate statistical significance.

\section{Results:}

A total of fifty patients (50) aged 20-55 years (mean age 34.1 \pm 8.1 years) were studied, out of which $35(70 \%)$ were females and $15(30 \%)$ males (M: F ratio was 1:2). Forty eight (96\%) were symptomatic while 2 (4\%) were asymptomatic. (See table 1$)$.

The mean $( \pm \mathrm{SD}) \quad \mathrm{CD} 4$ positive lymphocyte count of the HIV- infected patients was $217.7 \pm 144.8$ cells $/ \mu 1$ while that of control was $896.2 \pm 198.0$ cells $/ \mu 1$. The $p$ value was significant $(p<0.05)$.

The mean $( \pm$ SD) ESR of the HIV infected patients was $97.4 \pm 39.9 \mathrm{~mm} / \mathrm{hr}$ and that of control was $10.1 \pm 5.7 \mathrm{~mm} / \mathrm{hr}$, the $\mathrm{p}$ value was significant $(\mathrm{p}<0.05)$. The mean ESR $(86.0 \pm 36.8 \mathrm{~mm} / \mathrm{hr})$ of asymptomatic and symptomatic $(97.8 \pm 40.2 \mathrm{~mm} / \mathrm{hr})$ patients were significantly higher than those of the control group $(10.1 \pm 5.7 \mathrm{~mm} / \mathrm{hr})(\mathrm{p}<0.05)$. There was no significant sex variation of the ESR of both the HIV infected patients $(\mathrm{p}=0.079)$ and that of healthy control group (0.607). (Table 1$)$.

The mean $( \pm \mathrm{SD}$ ) Total WBC of HIV infected patients was 5,268 $\pm 1,601$ cells $/ \mu$ l while that of the controls was $5,454 \pm 2,283$ cells/ $\mu$ l. There was no statistical significant difference between Total WBC of the HIV infected patients and that of healthy control population $(\mathrm{p}=0.638)$.Table 2 .

The mean $( \pm$ SD) Absolute Lymphocyte Count (ALC) of HIV infected patient was $3283 \pm 691$ cells $/ \mu$ while that of controls was $4,746 \pm 1,263$ cells/up $(\mathrm{p}=0.000)$. There was a statistical significant difference between ALC of HIV infected patients and that of healthy control population $(\mathrm{p}<0.001)$. 
The mean $( \pm \mathrm{SD})$ Packed cell volume (PCV/Hemoglobin concentration) of HIV infected patients was $0.33 \pm$ $0.061 \mathrm{~L} / \mathrm{L}(10.9 \pm 2.0 \mathrm{~g} / \mathrm{dl})$ while that of the controls was $0.43 \pm 0.045 \mathrm{~L} / \mathrm{L}(14.3 \pm 1.5 \mathrm{~g} / \mathrm{dl})$. Similarly, the mean Haemoglobin concentration of HIV infected patients was significantly lower than that of healthy control population $(\mathrm{p}<0.001)$.

The mean $( \pm$ SD) platelet count of HIV infected patients was $157,000 \pm 81,979$ cells/ $\mu$ l while that of controls was $197,660 \pm 48,742$ cells/ $\mu \mathrm{l}(\mathrm{p}=0.003)$. The mean platelet count of HIV infected patients was significantly lower than that of the healthy control population $(\mathrm{p}=0.01)$ (Table 2$)$.

There was a poor inverse correlation between the CD4 + lymphocyte count and ESR of both the HIV infected and control $(\mathrm{r}=-0.18 ; \mathrm{r}=-0.11)$ respectively and a weak direct correlation between the CD4 of both HIV-infected and control with their respective ALC $(r=0.18 ; \mathrm{r}=0.24)$, Haematocit $(\mathrm{r}=0.07 ; 0.31)$ and Platelet count $(\mathrm{r}=0.05 ; 0.08)($ table 3$)$.

DISTRIBUTION OF ESR AND CD4+ LYMPHOCYTE COUNT AMONG STUDY GROUP.

[Table 1]

\begin{tabular}{|c|c|c|c|c|c|}
\hline & GROUP & $\begin{array}{l}\text { NUMBER } \\
\text { (n) }\end{array}$ & 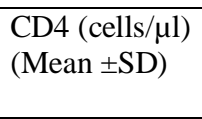 & $\begin{array}{l}\text { ESR } \\
\left(\mathrm{mm} / 1^{\mathrm{st}} \mathrm{hr}\right) \\
(\mathrm{mean} \pm \mathrm{SD})\end{array}$ & $p$-value \\
\hline \multirow[t]{3}{*}{ CONTROL } & & 50 & $896.2 \pm 198.0$ & $10.1 \pm 5.7$ & \\
\hline & Male & 41 & $903 \pm 210.4$ & $9.6 \pm 5.4$ & \multirow[t]{2}{*}{0.607} \\
\hline & Female & 9 & $865 \pm 132.7$ & $12.4 \pm 6.5$ & \\
\hline \multirow[t]{4}{*}{ PATIENT } & & 50 & $217.7 \pm 144.8$ & $97.36 \pm 39.8$ & \multirow{3}{*}{0.079} \\
\hline & Female & 35 & $236.4 \pm 118.9$ & $95.2 \pm 40.7$ & \\
\hline & Male & 15 & $174.1 \pm 94.3$ & $102.5 \pm 38.7$ & \\
\hline & $\begin{array}{l}\text { Asymptomat } \\
\text { ic }\end{array}$ & 2 & $330.0 \pm 169.7$ & $86.0 \pm 36.8$ & \\
\hline
\end{tabular}

Table 2

Comparative table of Haematological Parameters of HIV- infected and healthy control group.

[Table 2]

\begin{tabular}{|l|l|l|l|l|}
\hline $\begin{array}{l}\text { Measured } \\
\text { Parameters }\end{array}$ & $\begin{array}{l}\text { Control Subjects } \\
\text { Means } \pm \text { SD } \\
(\mathrm{N}=50)\end{array}$ & $\begin{array}{l}\text { HIV-infected } \\
\text { Patients } \\
\text { Means } \pm \text { SD } \\
(\mathrm{N}=50)\end{array}$ & p-value & $\begin{array}{l}\text { Statistical } \\
\text { Inference }\end{array}$ \\
\hline ESR $(\mathrm{mm} / \mathrm{hr})$ & $10.1 \pm 5.7$ & $97.4 \pm 39.9$ & $<0.05$ & Significant \\
\hline $\begin{array}{l}\text { Total } \\
\text { WBC }(\text { cellsmm }\end{array}$ & $5,454 \pm 2,283$ & $5,268 \pm 1,601$ & 0.63 & Not significant \\
\hline ALC $\left(\right.$ cells $\left./ \mathrm{mm}^{3}\right)$ & $4,746 \pm 1,263$ & $3,500 \pm 1,131$ & 0.000 & Significant \\
\hline PCV $(\mathrm{L} / \mathrm{L})$ & $0.43 \pm 0.045$ & $0.33 \pm 0.061$ & 0.000 & Significant \\
\hline $\begin{array}{l}\text { Platelets } \\
\left(\text { cells } / \mathrm{mm}^{3}\right)\end{array}$ & $197,660 \pm 48,742$ & $157,000 \pm 81,979$ & 0.003 & Significant \\
\hline & & & & \\
\hline
\end{tabular}

NB: ESR= Erythrocyte Sedimentation Rate; $\mathrm{PCV}=$ Packed Cell Volume; WBC=White Blood Count; TLC $=$ Total Lymphocyte Count; BMI=Body Mass Index.

Table 3.

Pattern of

\begin{tabular}{l|l|l|l|l} 
Pattern $\begin{array}{l}\text { latistical } \\
\text { statis } \\
\text { correlation }\end{array}$ & $\begin{array}{l}\text { Measured } \\
\text { parameters }\end{array}$ & CD4+ counts $(/ \mu \mathrm{l})$ & $\begin{array}{l}\text { r-value } \\
\text { HIV-infected }\end{array}$ & $\begin{array}{l}\text { r-value } \\
\text { control }\end{array}$ \\
\cline { 2 - 5 } & &
\end{tabular}

between

CD4+ count,

Haematological parameters in HIV infected and healthy control group. 


\begin{tabular}{|l|l|l|l|}
\hline ESR & CD4+ & -0.18 & -0.11 \\
\hline PCV & CD4+ & 0.07 & 0.31 \\
\hline WBC & CD4+ & -0.04 & -0.08 \\
\hline ALC & CD4+ & 0.18 & 0.24 \\
\hline $\begin{array}{l}\text { PLATELET } \\
\text { COUNT }\end{array}$ & CD 4+ & 0.05 & 0.08 \\
\hline
\end{tabular}

[Table 3]

\section{Discussion}

From this study, the patients' absolute mean CD4 positive lymphocyte counts $(217.1 \pm 114.8$ cells $/ \mu \mathrm{l})$ appeared to be relatively higher than values obtained in previous studies by Ndakotsu and coworkers ${ }^{6}$ among their cohort of $104 \mathrm{HIV}$-infected subjects in Ife where a mean value of $155.4 \pm 90.6$ cells/ $\mu \mathrm{l}$ was obtained from patients. This may be attributable to increased level of awareness of HIV infection in this region as the patients present early in our clinic.

We observed a control mean CD4 positive lymphocyte count of $896.2 \pm 198.0$ cells $/ \mu$ lamong HIVnegative healthy blood donors residing in Port-Harcourt in the Niger Delta region of Nigeria. This was consistent with values reported in previous studies by Idoko and coworkers ${ }^{7}(821 \pm 12$ cells/ $\mu$ l) in Jos, North Central Nigeria, but relatively higher than values reported in previous studies by Ejele and co-workers ${ }^{8}(685 \pm 99$ cells $/ \mu \mathrm{l})$ in Port-Harcourt, South-South Nigeria in 2005 and Ndakotsu and co-workers ${ }^{6}(655.7 \pm 17.6$ cells $/ \mu \mathrm{l})$ in Ife, South-West Nigeria in 2008. This may be due to improved nutritional status among the healthy HIVnegative controls coupled with increase awareness of the populace.

The data showed that the mean ESRs of the symptomatic $(97.8 \pm 40.2 \mathrm{~mm} / \mathrm{hr})$ and asymptomatic $(86.0 \pm 36.8 \mathrm{~mm} / \mathrm{hr})$ patients were significantly higher than that of the control $(10.0 \pm 5.7 \mathrm{~mm} / \mathrm{hr})(\mathrm{p}$ $<0.001)$. This was consistent with the previous studies by Ndakotsu and coworkers ${ }^{6}$ where the mean ESR of the symptomatic and asymptomatic patients were higher than that of the controls. The increase in ESR is because infection by Human Immune deficiency virus elicits an increase in the whole body's protein (including acute phase reactant proteins and lipoproteins) turnover. This increase in body's proteins is applicable to both symptomatic and asymptomatic HIV infected persons. ${ }^{9}$

There was a weak inverse relationship between ESR and CD4 positive lymphocyte count in both patients and controls $(r=-0.18$ and $r=-0.11$ respectively) (Table 5). This finding was in accordance with those of some previous studies ${ }^{6,10-16}$ where ESR was found to be a sensitive predictive marker of HIV disease progression.

There was a statistically significant difference between the mean haematocrit (PCV) of HIV infected patients $(0.33 \pm 0.06 \mathrm{~L} / \mathrm{L}$ or $10.9 \pm 2.0 \mathrm{~g} / \mathrm{dl})$ and that of controls $(0.43 \pm 0.045 \mathrm{~L} / \mathrm{L}$ or $14.3 \pm 1.5 \mathrm{~g} / \mathrm{dl})(\mathrm{p}<$ $0.001)$. However there was a significant inverse correlation between patients' ESR and their haematocrit $(\mathrm{r}=$ 0.46 ; $\mathrm{p}<0.05)$. The inverse correlation was weak in the control group $(\mathrm{r}=-0.15)$. This was in keeping with previous findings ${ }^{6,17}$ in which significant inverse relation was found between ESR and haematocrit $(p<0.001)$. Low haematocrit (anaemia), a common finding in HIV disease progression has a negative influence on ESR and could have contributed to the elevated ESR level in our patients. In addition to this, hypergammaglobulinemia, malnutrition, tropical diseases, which are also common findings in HIV/AIDS patients may contribute to the elevated ESR levels ${ }^{18,19}$. Therefore, HIV related anaemia increases the need for blood transfusion.

The data showed that there was no statistical significant difference between the total WBC of HIV infected patients $(5,268 \pm 1,601$ cells $/ \mu \mathrm{l})$ and the controls $(5,454 \pm 2,283$ cells $/ \mu \mathrm{l})(\mathrm{p}>0.05)$. There was a weak inverse correlation between CD4 positive lymphocyte count and total WBC in both the controls and the patients. Although leukocyte proliferation and the synthesis of cytokines, immunoglobulin and positive acute phase proteins contribute to protein turnover in HIV infection, this may not be the finding in all cases.HIV patients may also present with leucopenia which could be immune-mediated especially that resulting from anti neutrophil antibodies in some HIV- antibody positive patients ${ }^{20}$. Hence total WBC may not give good prediction of disease progression.

Though the mean ALC of HIV infected patients $(3283 \pm 691$ cells/ $\mu$ l) was statistically lower than that of controls $(4,746 \pm 1263$ cells/ $\mu$ l) there was a weak direct correlation between CD4 positive T- lymphocyte counts and ALC of both HIV-infected patients $(r=0.18 ; \mathrm{p}<0.05)$ and the controls $(\mathrm{r}=0.24 ; \mathrm{p}<0.01)$. This was similar to previous studies by Shapiro and Ejele and co-workers which showed that ALC could have a minimal predictive value to $\mathrm{CD} 4$ positive lymphocyte counts .

There was a weak direct correlation between CD4 positive lymphocyte counts and platelet counts of the patients $(r=0.05 ; p<0.05)$ and their controls $(r=0.08 ; p<0.05)$. This decrease in platelet count with disease progression may be immune-mediated as immune thrombocytopenic purpura is a common finding in AIDS $^{20,21}$. 
ESR was relatively higher in female $(12.4 \pm 6.5 \mathrm{~mm} / \mathrm{hr})$ than male $(9.6 \pm 5.4 \mathrm{~mm} / \mathrm{hr})$ in the controls but the difference was not statistically significant $(\mathrm{p}=0.607)$. (Table 1 ). This was similar to previous study where ESR was shown to be higher in female irrespective of infection or immune status ${ }^{6}$.

\section{Conclusion/Recommendation}

The findings from this study include the following;

1. Human immunodeficiency virus alters the immunological status of an individual, leading to deterioration of the clinical status and haematological parameters.

2. ESR of HIV-seropositve individuals irrespective of their clinical status (symptomatic or asymptomatic) are usually higher than that of healthy HIV-seronegative individuals.

3. Elevated ESR, decreased haematocrit, decreased absolute lymphocyte count (ALC), decreased platelet count (thrombocytopenia) and CD4 positive lymphocytopenia are useful indicators of HIV disease progression.

Simple low cost haematologic tests such as ESR, Haematocrit, WBC, ALC, and platelet counts should be used as indispensible accreditation baseline tests to access care and treatment of HIV/AIDS (HAART) in resourcelimited settings such as those in the Niger Delta Region of Nigeria.Apart from their roles in decision-making on when to start anti-retroviral therapy, they may also profer prognosticating role,hence they may be invaluable in monitoring the HIV disease progression and the response of patients to antiretroviraltherapy in situations where immunophenotyping (CD4 count) are not available.

\section{References}

[1] UNAIDS. Joint United Nations Programme on HIV/AIDS.AIDS epidemic update. November, 2007. UNAIDS information centre and World Health Organization (WHO) 2007.UNAIDS/O7.27E/JC1322E.

[2] UNAIDS. Joint United Nations Programme on HIV/AIDS.AIDS epidemic update. December, 2006.UNAIDS information centre in collaboration with World Health Organization (WHO) 2006.UNAIDS/06.29E.

[3] National HIV/Syphilis Sentinel Survey Reports. Nigerian Federal Ministry of Health. December 2006.

[4] UNAIDS:Reports on the global AIDS epidemic 2009.

[5] Modified National Policy on HIV/AIDS. Federal Ministry of Health in collaboration with Federal Government of Nigeria.May,2004

[6] Ndakotsu MA, Salawu L, Durosimi MA: Relation between Erythrocyte Sedimentation Rate, Clinical and Immune status in HIVinfected patients: Nigerian Journal of Medicine, 2009.Vol.17.No.4:420-422.

[7] Idoko JA, Idigbe JA, Njoku MO, Sirisena ND, Isamade ET, et al. CD4 T-lymphocyte count in HIV-infected Healthy Nigerian population. Nigerian Medical Practitioner 2001;39:53-55.

[8] Erhabor O, Nwauche CA, Ejele O.A, Babatunde S: CD4 positive lymphocyte reference ranges in healthy adults in Port-Harcourt, Nigeria. Sahel Medical Journal Vol 8 No.3 July-September,2005;71-75.

[9] Ogunro PS, Idogun ES, Ogungbamigbe TO, Ajala MO, Olowu OA: Serum concentration of acute phase proteins and lipid profile in HIV-1 seropositve patients and its relationship to the progression of disease. The Nigerian postgraduate Medical Journal, 2008; Vol 5.No 4(219-224).

[10] Lefrere JJ, Salmon D, Doinelet. al. Sedimentation rate as a Predictive marker in HIV infection. AIDS 1988 Feb;2(1):63-4.

[11] Schwartlander B., Bek B, Skarabis H, et al: Improvement of Predictive value of CD4 count by beta 2-microglobulin, IgA and ESR. A multicentre cohort study group. Federal Health Office Berlin Germany. AIDS 1993 June 7(6):812-21.

[12] Papadopulos-Eleopulos E, Turner VF ,Papadimitriou J.M. et al.: High rates of HIV seropositivity in Africa-alternative explanation. International Journal of STD and AIDS 2003.

[13] Modjarrad K, Zulu I, Karita E, et al: Predictors of HIV sero-status among HIV discordant couples in Lusaka Zambia and female Antenatal clinic attendants in Kigali, Rwanda AIDS Research Human Retrovirus 2005; 21:5-12.

[14] Lindan CP, Allen S, Sanifilira A. et al.:Predictors of mortality among HIV-infected women in Kigali, Rwanda. Ann Intern.Med.1992;116:320-328.

[15] Lifson A.R, Allen S, Wolf W et al: Classification of HIV infection and disease in women from Rwanda.Evaluation of the World Health Organization HIV staging system and recommended modifications. Ann Intern Med.1995;122:262-270.

[16] Perez de Oteyza C, Menendez Martinez MA, Muro Garcia R, Perez Aznar C, Barberan Lopez J: Discriminative value for AIDS case of Erythrocyte sedimentation rate, Immunoglobulins A and M, and beta 2-microglobulin in combination with the CD4 positive lymphocyte count. Ann MedInterna 1998;15:411-414.

[17] Hung WT, Collings AF, Low J: Physics in Medicine and Biology. 1994.39:1855-1873.

[18] Costello C. The Haematological manifestations of HIV disease. In:Hoffbrand A.V., Lewis M.S., Tuddenham E.G. (eds). Postgraduate Haematology. 4th edition. London: Arnold, 2001: 310-313.

[19] Costello C. Haematology in HIV diseases. In: Hoffbrand A.V., Catovsky D., Tuddenham E.G. (eds). Postgraduate Haematology. 5th edition. Oxford: Blackwell, 2005: 383-385. 